\title{
French life insurance lexicography in Canada
}

\author{
Sabrina Aulitto \\ Seconda Università di Napoli - Capua (CE), Italy \\ sabrina.aulitto@unina2.it
}

\section{ABSTRACT}

In Canada, insurance terminology has long been living a linguistic emergency situation. This paper proposes the study of three different lexicographical works written by French authors of Canadian origin, aimed at normalizing the use of this lexicon. This need started at the end of 19th century, as testified by the Dictionnaire français-anglais et anglais-français sur la vie written by Naraire Payette. This tradition had its great development in the 1960s, when translators and terminologists launched the refrancization project of the insurance sector, promoted by the Office de la langue française.

\section{Indexing terms/Keywords}

Life insurance terminology; bilingual dictionary; refrancization.

\section{Academic Discipline And Sub-Disciplines}

Linguistics, terminology, trasnslation, lexicography

\section{SUBJECT CLASSIFICATION}

French language, economics language

\section{TYPE (METHOD/APPROACH)}

\section{Lexical analysis}

\section{Council for Innovative Research}

Peer Review Research Publishing System

Journal: Journal of Advances in Linguistics

Vol 6, No. 2

editor@cirjal.com

www.cirjal.com, www.cirworld.com 


\section{INTRODUCTION}

In this paper, three bilingual dictionaries of life insurance terminology are analysed. The first dates back to the 19th century. It is the Dictionnaire français-anglais et anglais-français sur la vie written by Nazaire Payette. The second is the Vocabulaire des assurances sur la vie (1969) published by the Office de la langue française, under the direction of JeanPaul de Grandpré. The third is the Vocabulaire technique des assurances sur la vie. Terminologie technique et industrielle vocabulaire anglais-français, collected by Louis-Paul Béguin. Although these works present three different structures, they share the same aim of normalizing this terminology for a more precise communication in this specialized context.

\section{NazaiRe PayetTE's DictionaRY}

The only example of bilingual dictionary published at the end of 20th century was written by Nazaire Payette, the Dictionnaire français-anglais et anglais-français sur la vie, 1899 (Payette, 1899). This author, after a long career in English life insurance, also had the chance to work in a French insurance company. During this period he met great difficulty in translating English insurance concepts into French, and he realized that some French terms were used in an incorrect way. For this reason, he chose to publish this Dictionnaire in order to normalize the use of this limited number of key terms. This work announces the Canadian terminology emergence ante litteram, and tries to give some practical, personal and useful terminology solutions, by suggesting the most correct French and English terms.

From the microstructure analysis, it is possible to observe that the author does not respect the traditional article organization, because he did not include definitions, examples, synonyms and antonyms. The dictionary presents only 131 French terms with their English translations and only 83 English terms with the French translations. The limited number of terms could be associated with Payette's difficulty in dealing with terminological issues. Considering its structure, this work can be defined as a glossary with an informative aim, rather than a dictionary. In addition to the French or the English equivalent, the author adds two fields relating to life insurance: industrial and tontine sectors.

Here are some examples:

1. Débit percevable (industriel) $=$ Collectible debit (Industrial)

2. Salaire ordinaire (industriel) $=$ Ordinary salary (Industrial)

3. Salaire spécial (industriel) = Special salary (Industrial)

4. Dividendes réservés (tontine) $=$ Reserved dividends (Tontine)

5. Siège social $=$ Head office (English) $/$ Home office (American)

Regarding the industrial field, it should be noted that the development of life insurance owes much to industrialization. Towards the end of the nineteenth century many workers had life insurance to protect against accidents, possible diseases, death. As a matter of fact, this aspect can be noted by the presence of some terms and lexical combinations which underline the close link between life and death.

For instance:

1. Death claim = Réclamation de décès

2. Expectation of life $=$ Durée probable de la vie

3. Equation of life = Equation de la vie

4. Mortality $=$ Mortalité

With the passing of time, the relationship between doctors and companies will become stronger, since the Companies requested to be informed about health conditions of their customers so that they could possibly refuse to insure them. So, towards the end of the nineteenth century, several companies administered their insured a questionnaire about their families ( Comiti).

During this period, insurance terminology was enriched by medicine, statistics and mathematical terms, because the actuarial calculation became part of life insurance practice. Also, the actuary was an important figure in the insurance world, and it had already been a word in Payette's Dictionnaire: actuary = actuaire.

Payette's dictionary could be considered an attempt of bilingual terminology insurance systematization, which will be successively perfected and updated, thanks to more organized lexicographical works.

\section{JEAN-PAUL DE GRANDPRÉ: The FIRST ARTISAN OF INSURANCE TERMINOLOGY FRANCIZATION AT 19TH CENTURY}

In 1969, the Office de la langue française of Quebec published the Vocabulaire des assurances sur la vie (Grandpré, 1969) under the direction of Jean-Paul de Grandpré, translator of an insurance life company.

The Vocabulaire des assurances sur la vie is the result of a teamwork achieved with the collaboration of experts, such as actuaries, life-insurers and insurance employees. It presents a list of terms in order to avoid inferences and translation mistakes. It wants to be not only a reference tool for translators, but also a real support for life insurers to well interpret official documents. It is important to highlight that Francophone countries do not have the same insurance legislation; in 
fact, there are some differences between European and American regulations which cause terminological questions and the emergence of normalization.

The Vocabulaire des assurances sur la vie collects 223 French terms with the English translations and the French definitions. In the final part of the work we can find:

- $\quad$ A list of English terms.

- $\quad$ A list of fault forms.

- A list of terms not in alphabetical order.

- The bibliography.

It is interesting to compare some terms of Grandprés Vocabulaire with Payette's Dictionaire. The comparison points-out that there are some similarities, but also numerous differences.

Three different kinds of phenomena can be observed:

- Equal translation

- Semi-equivalent translation

- $\quad$ Lack of equivalence

- Below, three tables illustrate some examples of the first two phenomena:

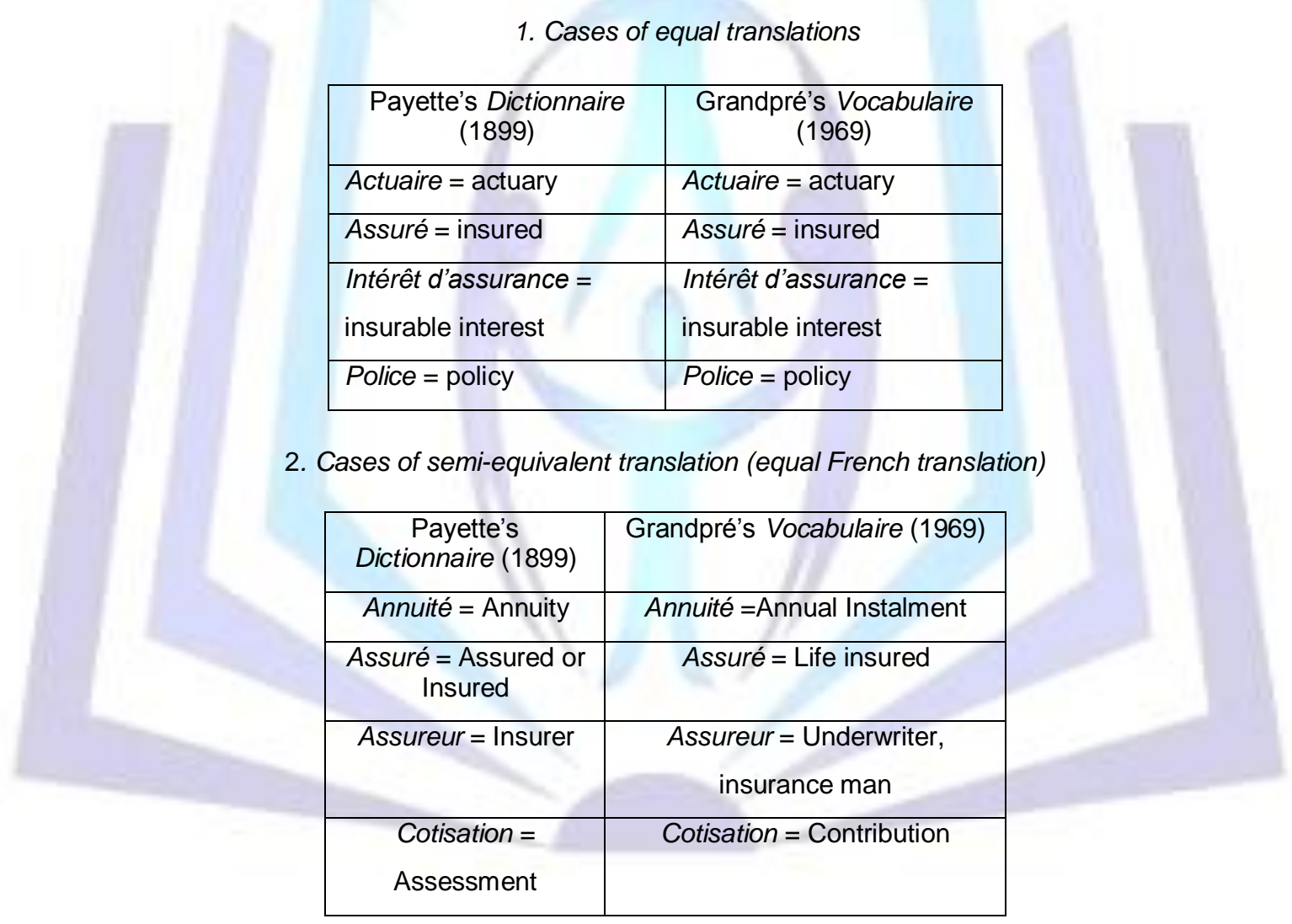

3. Cases of semi-equivalent translation (equal English translation)

\begin{tabular}{|c|c|}
\hline $\begin{array}{c}\text { Payette's } \\
\text { Dictionnaire (1899) }\end{array}$ & Grandpré's Vocabulaire (1969) \\
\hline Accumulation $=$ & Capitalisation = \\
accumulation & accumulation \\
\hline $\begin{array}{c}\text { Applicant }= \\
\text { souscripteur }\end{array}$ & Proposant = applicant \\
\hline Claim = réclamation & Demande de règlement = claim \\
\hline Industrial insurance & Assurance populaire = \\
\hline
\end{tabular}




\begin{tabular}{|c|c|}
\hline $\begin{array}{c}\text { = Assurance } \\
\text { industrielle }\end{array}$ & industrial insurance \\
\hline Loading = surcharge & Chargement = loading \\
\hline
\end{tabular}

As concerns the lack of equivalence, the lexical combinations of premium is particularly significant.

Premium = prime, as a single term, is a case of equal translation, but studying the translations of the word's lexical combinations, it results that many of these are only in Payette's Dictionnaire or in Grandpré's Vocabulaire and vice versa.

This is the case of prime annuelle = annual premium, or prime hebdomadaire = weekly premium. They are present in Payette's Dictionnaire, while they are completely absent in Grandpré's Vocabulaire.

For further details, all the combinations are put in the table below :

\section{Premium/ prime lexical combinations}

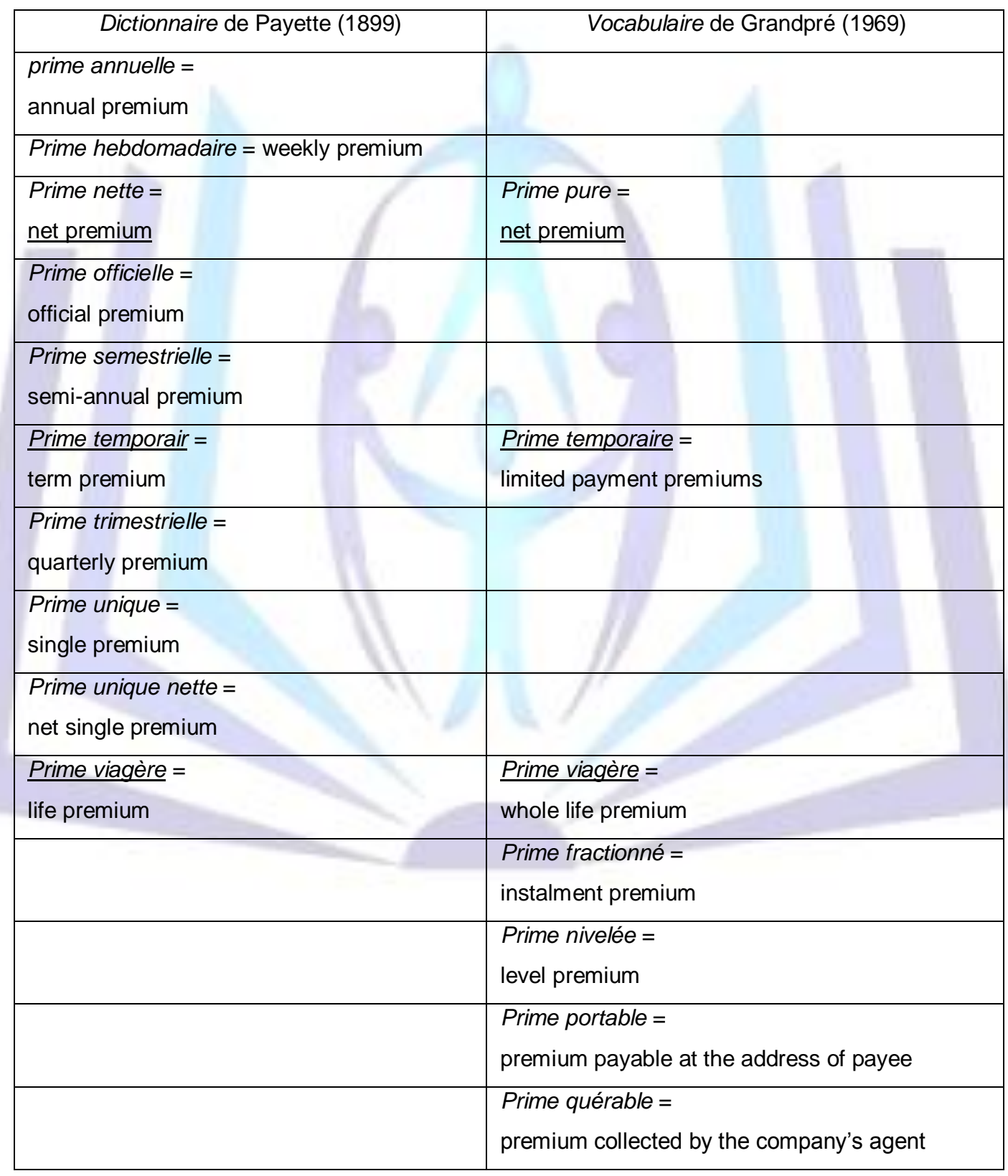


It is possible to emphasize the only three cases of semi-equivalence:

- $\quad$ Prime nette $=\underline{\text { net premium }} \sim$ Prime pure $=\underline{\text { net premium }}$

- $\quad$ Prime temporaire $=$ term premium $\sim$ prime temporair $=$ limited payment premiums

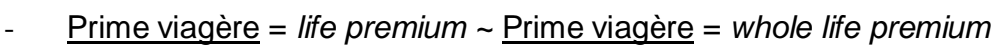

In all the other lexical combinations there are not the english translations in the two lexicographical works. This could signify that, on the one hand, Payette's lexical combinations have fallen into disuse, because the insurance practice has developed and these terms are not part of this specialized communication any longer. On the other hand, Grandpré's lexical combinations have been introduced with the sector update and development.

This terminological evolution underlines how specialized communication changes in accordance with the exigencies and developments in the insurance-field and, for this reason, it needs to describe and to well define the terminology in use through lexicographical and terminographic works.

\section{LOUIS-PAUL BÉGUIN AND REFRANCIZATION OF LIFE INSURANCE TERMINOLOGY}

Louis-Paul Béguin continued Grandpré's work and directed the refrancization insurance project at the Office. He rejected the large number of Anglicisms in use, which caused morphological and syntactic mistakes, in case of literal translation.

His first work was the Vocabulaire correctif des assurance (Béguin, 1979), published in 1979. After 11 years, Béguin, with the collaboration of Grandpré and Lucien Forges, proposed a new updated version called Vocabulaire technique des assurances sur la vie. Terminologie technique et industrielle vocabulaire anglais-français (Béguin, 1990).

This Vocabulaire contains more than 500 English terms followed by:

- domaine d'emploi

- défintion anglaise

- équivalent français

- définition française

- renvoi

- justifications

- variante

- observations

- synonymes

- antonyme

The domain d'emploi of each term is indicated. These fields are specified after the introduction, where eight codes are listed to identify the different fields in which insurance intervenes.

The list of the codes included is as follows :

01. Termes généraux - Assureurs-Assurés

02. Catégories d'assurance

03. La garantie et ses modalités

04. Primes-Commissions

05. Sinistres - Indemnités

06. Contrat d'assurance et gestion des contrats

07. Gestion administrative et financière des entreprises d'assurance et règlementation

08. Termes particuliers

These codes are an important reference for translators, who could easily identify the application field of every single entry. The accident terminological file shows an example of the Vocabulaire microstructure structure: 


\section{Accident}

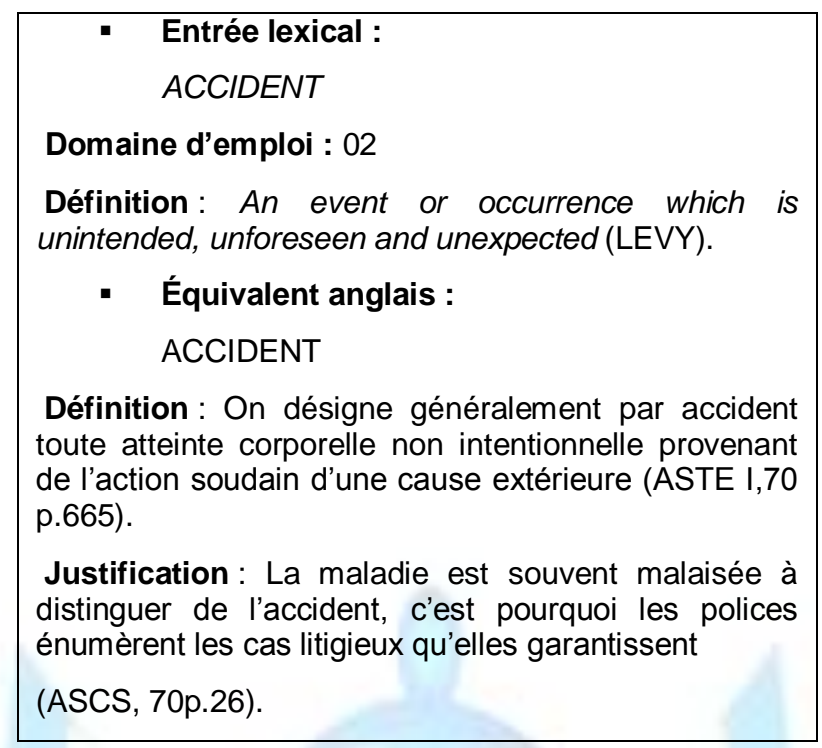

The information is well organized and rich in details. In addition, the definition and the justification are formulated according to the sources listed in the bibliography placed at the end of the Vocabulaire.

This kind of definition could be explained "in context", because the author does not choose to reformulate the concept, but to use specialized writings as source for definitions.

Following are three other terminological files:

- $\quad$ "product" contains the variant and the observation

- " "quota-share insurance" which presents the synonyms and the renvois

- "Bona fide", for the presence of antonyms

\section{Product}

Entrée lexical :
PRODUCT
Domaine d'emploi : 07
Définition : In life or health insurance, the policies
sold by a company (LEVY).
$\quad$ Équivalent anglais :
$\quad$ CONTRAT(S)
Définition: Désigne l'ensemble des contrats
pratiqués par une Compagnie pour souligner l'intérêt
qu'ils peuvent susciter chez le public preneur (d'après
PHEN, Q128).
Justification : Les sociétés ...ont mis au point un
contrat présentant les caractéristiques exigées par
l'administration (AVIE, M ${ }^{8}$ ).
Variante :
Garantie
Son travail ne sera terminé dans un foyer que
lorsqu'il aura assuré tous les membres de la famille qui
sont assurables et à qui les garanties peuvent être
utiles. ( PHEN, Q128)
Observation : En langue familière et publicitaire,
product se rend par produit.




\section{- Entrée lexical :}

QUOTA-SHARE REINSURANCE

Domaine d'emploi : 07

Définition : Acceptance by the reinsurer of a share of the risks of the reinsured, the two sharing all losses and expenses as agreed (LEVY).

\section{- Équivalent anglais :}

\section{Réassurance en participation}

Définition: Forme de réassurance selon laquelle l'assureur est déchargé d'une partie des risques, mais d'une façon uniforme pour tous les risques lesquels elle porte ( ASTE II, 65 p.283).

Justification : La réassurance en aprtecipation ou en quote-part n'est pas tout à fait adéquate à l'objet propre de la réassurance quiest, a-t-on dit, de supprimer les écarts en égalisant les risques: elle réduit les risques pas (ASTE II, 65 p.283).

Synonyme: Réassurance en quote-part (ASTE II, 65 p.283) - ( PHEN, G205)

Renvois. Voir aussi SURPLUS SHARE REINSURANCE

Voir aussi EXCESS OF LOSS REINSURANCE

Voir aussi STOP-LOSS REISURANCE

\section{Bona fide}

\section{- Entrée lexical :}

\section{BONA FIDE}

Domaine d'emploi : 06

Définition: Made in good faith without fraud or deceit:sincere (WEBM)

- Équivalent anglais :

\section{DE BONNE FOI}

Définition : Qualité de celui qui parle, agit avec une intention droite ( Robe).

Justification: La proposition doit être rédigée de bonne foi par le souscripteur ( AVIE, D ${ }^{2}$ ).

L'article ... s'applique même à un assuré de bonne foi ( BART, p.80)

Antonyme : mauvaise fois

L'omission ou la déclaration inexacte de la part de l'assuré dont la nauvaise foi n'est pas établie ( BART, p.80).

Another interesting aspect of this Vocabularaire is the last part: the Annex, which includes the organization chart of an life insurance company. This explanation could be useful for the new insurance employee, but also for translators who are called to translate specialized texts, where there is a need to know the hierarchic order of a big insurance company. 
Below the four sections are illustrated:

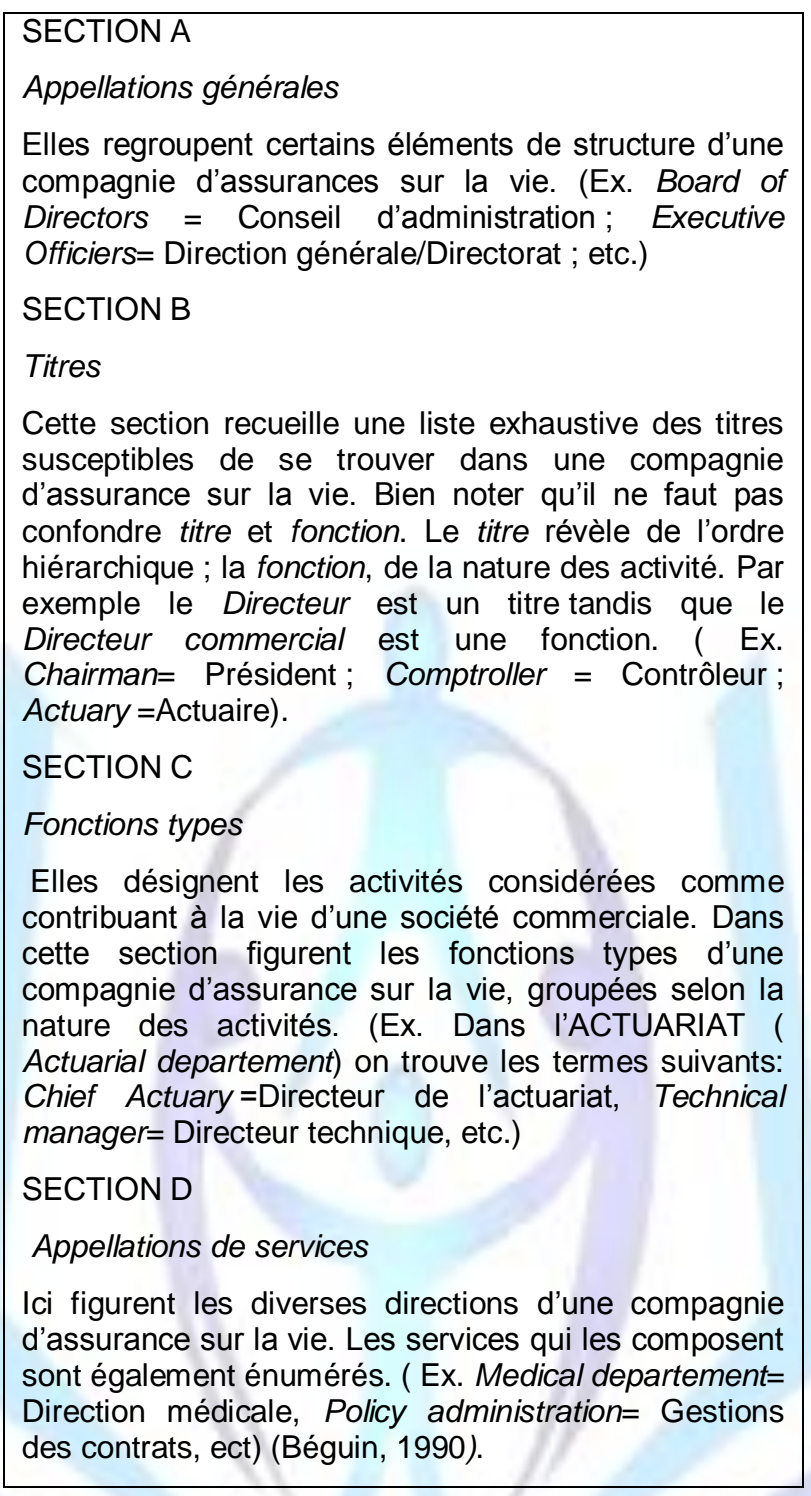

This organization is not in use in all insurance companies, because there is not a normalized and unique terminology to define the hierarchic order. So, this wants to be only an approximate example to consult and to then be verified in the specific reference context.

\section{CONCLUSION}

This analysis has tried to show how life insurance terminology has changed throughout a century (1899-1990), in accordance with the development of the insurance sector.

Through the study of these three lexicographical works, we have observed three different ways to solve the terminological emergency.

Payette perceives this linguistic situation and tries to give his contribution, even if he deals with a very limited number of terms.

Grandpré achieves a more complete and organized Vocabulaire, with a clear idea of how to define the various entries.

In the end, Béguin builds a valid and authentic product, which could be a real and concrete tool for everyone who is interested in deepening life insurance knowledge.

\section{'REFERENCES}

1. Béguin L-P., 1979, Vocabulaire correctif des assurances, Office de la langue française, Québec.

2. Béguin L.-P. \& al. 1990, Vocabulaire technique des assurances sur la vie: vocabulaire anglais-français, Publications du Québec, Office de la langue française, Québec. 
3. Comiti v.p., Histoire des assurances sur la vie à la fin du siècle e tau début du XXe siècle, available on the

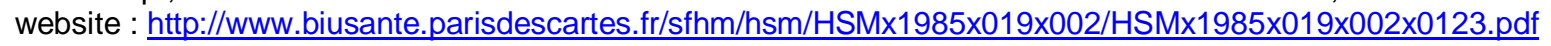

4. Grandpré J.-P., 1969,, Vocabulaire bilingue des assurances sur la vie, Editeur Officiel du Québec, Office de la langue française, QuébeC.

5. Payette N, 1899, Dictionnaire français-anglais et anglais-français des mots en usage dans l'assurance sur la vie, Montréal.

${ }^{[1]}$ Payette N, Dictionnaire français-anglais et anglais-français des mots en usage dans l'assurance sur la vie, Montréal, 1899.

${ }^{[2]}$ V.-P. Comiti, Histoire des assurances sur la vie à la fin du siècle e tau début $d u$ XXe siècle, available on the website:

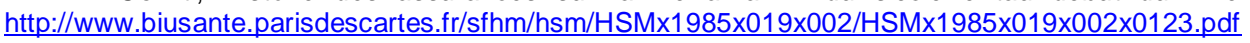

[3] J.-P. Grandpré, Vocabulaire bilingue des assurances sur la vie, Editeur Officiel du Québec, Office de la langue française, Québec, 1969.

${ }^{[4]}$ The lexicographical works consulted are: the Grand Larousse encyclopédique, Larousse du XXe siècle, the Dictionnaire alphabétique et analogique de la langue française by Paul Robert (1960) and the Vocabulaire des assurances sociales, published by the Office.

[5]' Louis-Paul Béguin born in France in 1923, came to Canada in 1960 and first settled in Toronto, where he worked for an insurance company. In 1968, he published in Meta, translators review an article, La refrancisations des assurances et ses consequences, witch that describes some difficulties that existed at the time the French language in this area. Louis-Paul Béguin moved to Quebec in 1970 . He worked for several years in Quebec and then goes to Montreal. He became known for his columns in the language Nouvelliste and Le Devoir but also as head of the French language terminology of insurance to the Office of the French language.

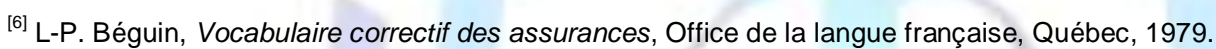

${ }^{[7]}$ L.-P. Béguin $t$ al., Vocabulaire technique des assurances sur la vie: vocabulaire anglais-français, Publications du Québec, Office de la langue française, Québec, 1990.

' [8] Ibid., pp. 99-109. 